\title{
炭渗劑に就きて
}

會 $\mathrm{R}$.

O. 生

锘近オートバイ、自働車及び飛行機等の製造工゙業が著しく盛んになつた。之等の製造には表 面硬化を施す可き部分が多いから從つて表面硬化の操業も亦著しい進步を來たした。

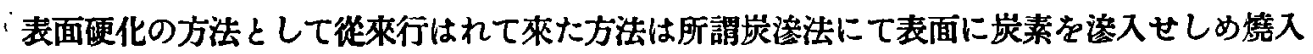
れに因つて表面を硬化する方法である。最近表面硬化の一方法として窒化法が盛んに研究さ れるに至つたが此の方法には未だ威多の缺點を有する。即ち窒化法は甚だ長い時間を要する事

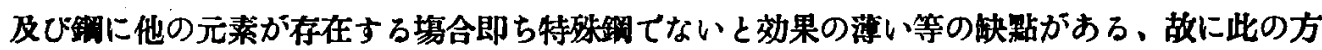
法は未た研究時代と云つて良からう。要するに現在に於て表面硬化の安全なそして簡單な方法 は炭渗法なのであろ。

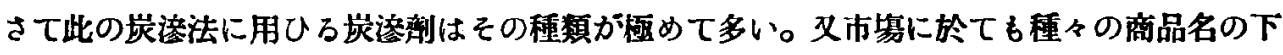

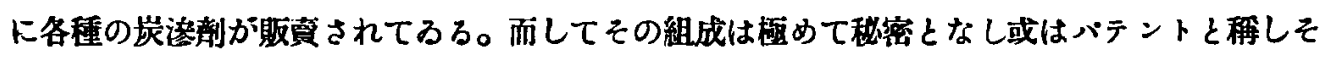
の値も極めて高い。筆者は今日に至万も向ほ斯から得體の知れない不可思議なる物に對し高偪

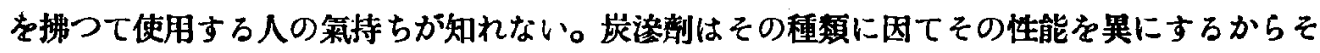

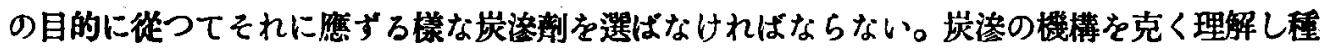

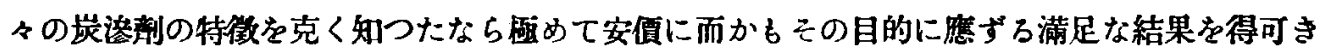
炭㳒劓客容易に得られるのである。

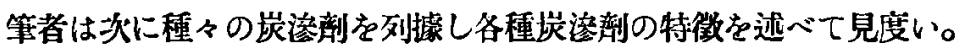

炭港㻭はその使用狀態から炏の四種に分類する事が出來る。

1. 固䱏岸港劑

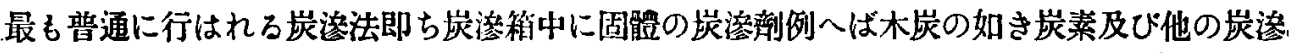

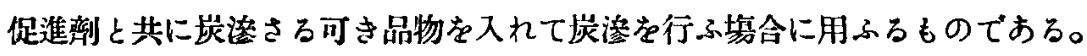

$\because 2$. 液體炭港制

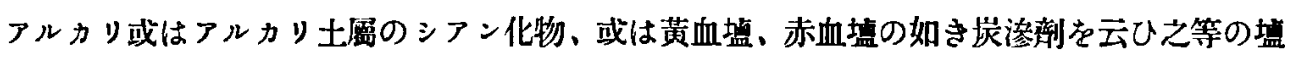

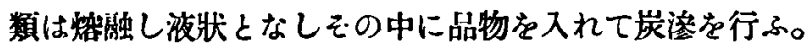

3. 正斯狀宸澎

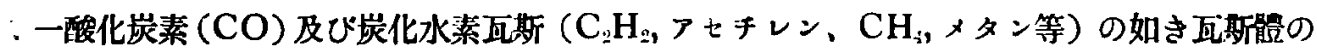


埃渗楌

4. 混合岸渗割

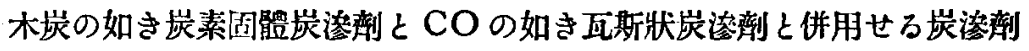

又炭灙剩はその炭渗速度に依て炏の二種類に分つ事が出來る。

a) 急速に炭窑す万炭淩峦

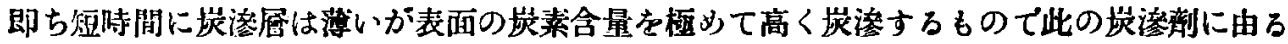
洔は往々にして表面制離ななす慮がある。

b）炭素含量を徐↔に篮じて炭潦する炭港制

即ち表面の炭素含量に䍱り高くないが內部に至るに從ひ炭素含量が極めて徐々に減少するも

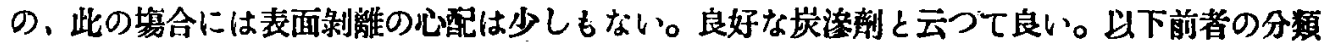

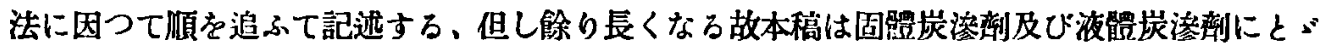

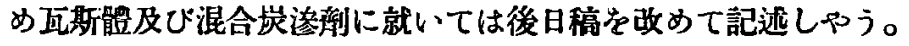

現在に於て實際に使用されてる物で次に述べる椂に極めて簡單な配合で而かもその結果の甚 だ良好な二三の代表的炭㴰蔀がある。此の簡單な配合の物へ無暗に他の物を加へても決してそ の結果は良好とならない。のみならず往々にして製品に不純物が入り又製品が揃はない榡にな

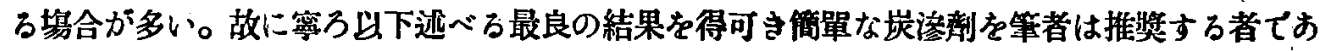
ל。

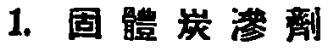

(A) 炭、素 粉

固體炭渗劑の中最も簡單な物は粉碎せる崖素末である。そしてその炭素の中最も純粹な物は

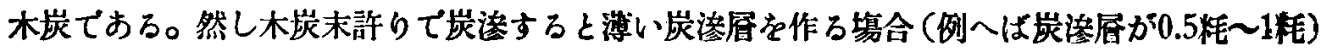
には表面の炭素含量が粫めて少なく又炭渗され方の一樣でない缺點がある。

故に純粹な木炭よりは寧乃多少の不純物例へば完全に分解してるない有機物の殘渣或は炭化 水素互斯字發生す可き不純物等を含む他の形の炭素が用ひられる事がある。例へば骨炭、革

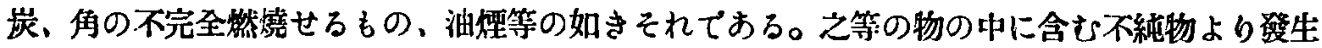
する炭化水素瓦斯或は $\mathrm{CO}_{2}$ 又はシアン瓦斯は炭素の存在に於て甚しく炭洷な促進せしめるの である。之等の物を用ひるには何れるよく粉碎し乾燥しなければならない。及この目的に應じ てめ上の各種の炭素含有物を種々に配合して炭素の澺入する量を加減する。勿論之れは使用者 
の䉺驗に依り又爐の炭㑢さる可き品物の條件等も考へてその配合を變じなければならない。 今例を宗せば

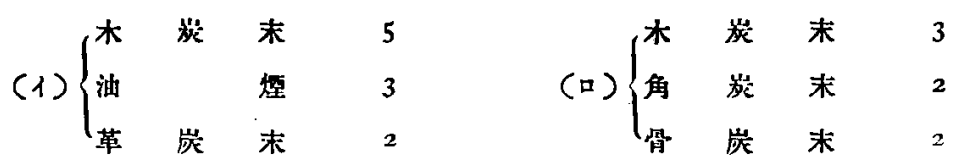

の如きである。

然し木炭末許りではその表面の含炭素が少な過ぎると云ふ溙な塲合に用ひられるちのであ ろ。

然し革炭及び骨炭等を用ふ万塲合には次の樣な事を注意しなければならない。即ち革炭には

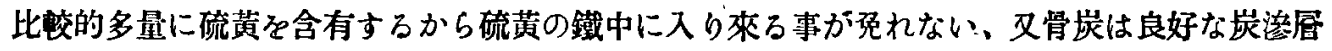
が得られ其の上檤段も安い核に見へろが賽はそうでない。何となれば新しい骨炭を加へずに數 回炭洷を行ふ時は却つて脫炭を來しその炭㳒能力を失ふ事が極めて早いからである。

(B) $\begin{array}{lll}\text { 木 } & \text { 炭 } & 20 \text { 分 } \\ \mathrm{NaCl} & & 10 \text { 分 }\end{array}$

此の炭洷剂は非常に簡單な混合物で而かる濢山の人の推獎する所であるが $\mathrm{NaCl}$ が何故に 炭參を促進するか未だ科學的說明が與へられないのである。此の炭渗峦は多くの機械工塲で用 ひられてるる。

(C) 物状 $60 \%$

此の炭㳒劑は Caron's cement と释し簡單の配合で而かも最良の結果を得るものである。 宸酸バリウムの働きは分解して出て來る $\mathrm{CO}_{2}$ が炭素と作用して $\mathrm{CO}$ 瓦斯を作り炭渗作用定 なすもので外の炭洷剂に比し極めて均一に炭洷せられ不同を少なくする利益がある。此の炭淩 㓩を用ひて $900^{\circ} \mathrm{C}$ 附近で炭港すると表面 $0.7 \sim 0.8 \% \mathrm{C}$ の含炭量を得 $1100^{\circ} \mathrm{C}$ に於ては表面

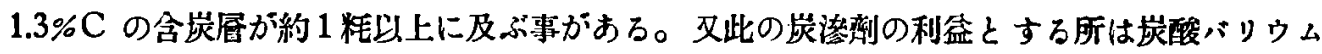
を回览し得る事である。即ち分解して生じた $\mathrm{BaO}$ は空氣中に放置すると $\mathrm{CO}_{2}$ を取り再び $\mathrm{BaCO}_{3}$ となるから甚だ㮒臂である。

此の炭渗剮は克く替り合せて用ふる。若し外の條件が一定なれれば炭酸バリウムと炭素の比を 種なに㱍ずればその結果も亦それに應じて暴つて來る。

Guillet の賽驗に依れば Caron's cement を用ひ $0.05 \% \mathrm{C}$ の武料を $1000^{\circ} \mathrm{C} て ゙ 8$ 時間炭澺 
し厚さ 0.25 籷宛制り取り分析の結果は次表の示す通りであら。

\begin{tabular}{|c|c|c|c|}
\hline \multicolumn{2}{|c|}{ 㟶臸刺の組线 } & \multicolumn{2}{|c|}{ 炭素留 $(\%)$} \\
\hline 木㟶 $(\%)$ & $\begin{array}{c}\text { 炭酸バリウム } \\
(\%)\end{array}$ & 第一居 & 筆二層 \\
\hline 80 & 20 & 1.14 & 0.75 \\
\hline 60 & $4^{\circ}$ & 132 & 1.19 \\
\hline 40 & 60 & 0.94 & 0.77 \\
\hline
\end{tabular}

埮酸バリウム許りでなく他の壏類例へば $\mathrm{NaCl}$ を用ひ

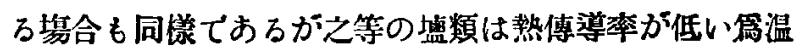
度が上り難いと云ふ缺點がある。前述の木炭を主成分と して有機物を配合せる炭泈群は此の熱傳導率と云子點に 於いては優つてるろか，他の點に於ては Caron's ce-

mentに道かに及ばない。

$\begin{array}{lll}\text { (D) } & \text { 岸 } & 10 \sim 12 \% \\ \mathrm{Na}_{2} \mathrm{CC}_{3} & 93 \sim 58 \%\end{array}$

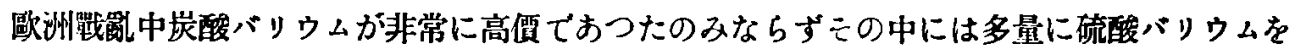

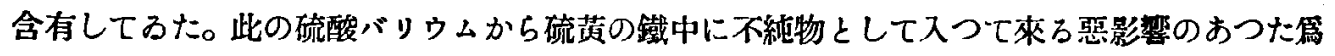
$\mathrm{BaCO}_{3}$ の代りに $\mathrm{Na}_{2} \mathrm{CO}_{3}$ が用ひられるに至つた。此の炭渗峦の利とする所は

（1） $\mathrm{Na}_{2} \mathrm{CO}_{3}$ は曹達灰として睛入する事が出來て安價な事

（2）容易に混合し得られる事

(3) $\mathrm{Na}_{2} \mathrm{CO}_{3}$ は始んこ無制限に用ひられる事

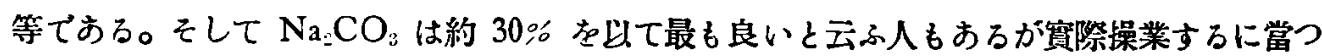

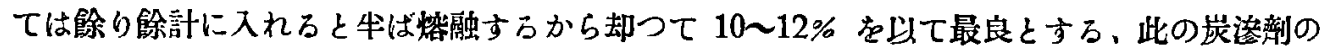
製法は

（a）临水炭酸曹達を用ひ出來るだけ良く木岸と混合するか及は

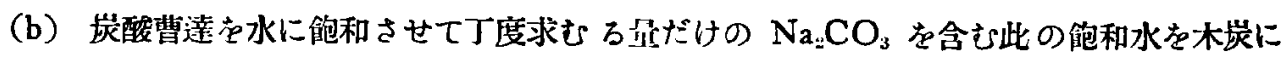
䎵み込ませた後乾燥する

(b) の方が賽際操涤の結果は良好である。

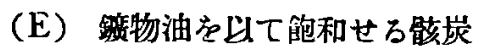

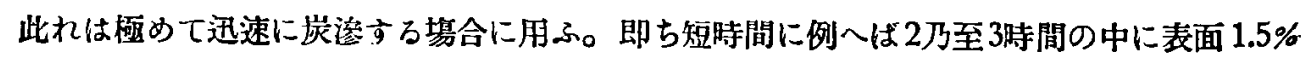
乃至 $1.8 \%$ (崖洷温度に依て)の炭素を含有する薄い居を得られる。

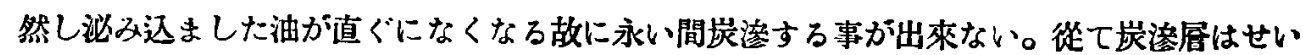

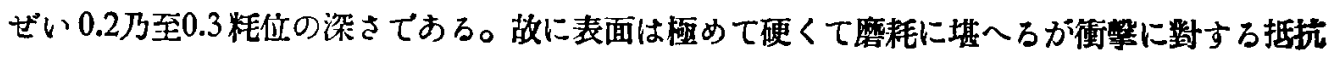
は少なく剩離の心配がある。 


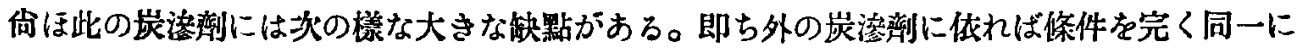
する時はその結果し大體均一な結果を得られるが此の炭湆剖に由ては如何に操業法を調制して も一定の製品を得る事が困難でおる。

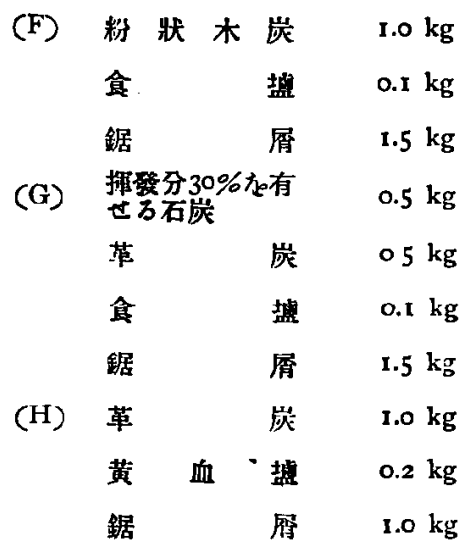

以上 $(\mathrm{F}) 、(\mathrm{G})$ 及び (H)の三種の炭渗乵は (F)ょり $(\mathrm{H})$ に至るに從ひその炭济速度を增加

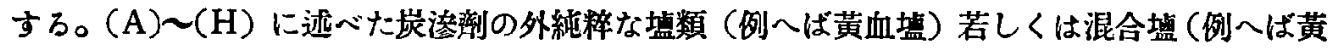

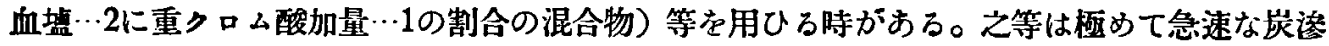

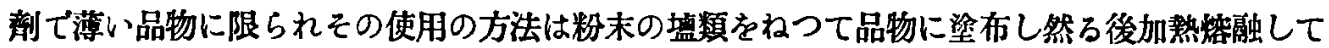

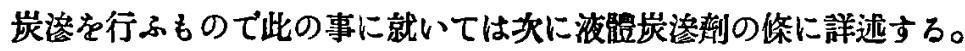

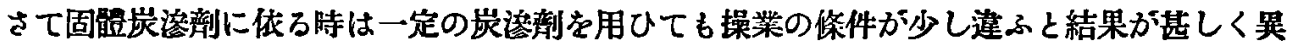
なつて來る。例へば嘘の構造、炭港箱、品物の形狀、大さ、炭㳒箱中に於ける品物の配置等の 相違に依つてその結果も違つて來る。故に多くの著者に依り發表されたるのでその炭淩酩、炭

\begin{tabular}{|c|c|c|c|c|}
\hline 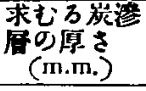 & \multicolumn{2}{|c|}{ 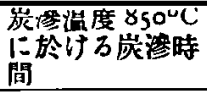 } & \multicolumn{2}{|c|}{ 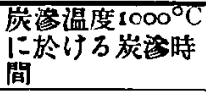 } \\
\hline 0.5 & \multicolumn{2}{|c|}{ 2時閒30分 } & \multicolumn{2}{|c|}{ 。時間30分 } \\
\hline 0.8 & & $"$ & $\mathbf{I}$ & " \\
\hline 1.0 & 6 & $n$ & 2 & $"$ \\
\hline 1.2 & 7 & $"$ & 3 & $"$ \\
\hline 1.5 & 8 & $"$ & 4 & " \\
\hline 2.0 & & $\cdots$ & 6 & " \\
\hline 2.5 & & $\cdots$ & 8 & $" \prime$ \\
\hline
\end{tabular}

表中㞸渗時間ささろは炭箱の外部が $850^{\circ} \mathrm{C}$ 久は1000ㄷ
㳒時間、及じ炭㳂温度が同じでも得られた炭 渗蒼の厚さ及び炭素含量が區々としてるる。

今左に一例として Guillet に体る結果を舉 げて見やう。

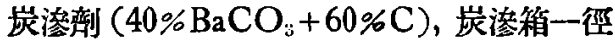
12 糎の鐵板製のもの、品物の周圍に於け万宸 洷剖の厚さ5糎、

以上逝ベた炭渗乵の中 (A)、(B)、(E)、(G) 及び (H)は急速崖洛峦で (C)，(D) 及び (F) 


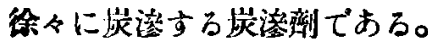

即ち前者は外居に於て炭菜含量が急激に上昇し永離する虑れがあるが短時閒に表面に高炭素 の外居を得られるから急激な衙揧を受けず、唯磨堿に耐へれば良いと云ふ品物に施される。例

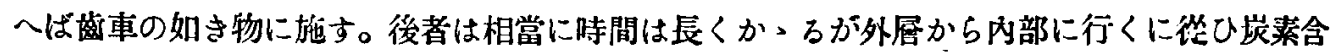

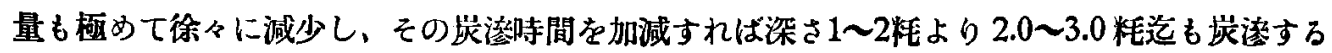
事が出來て燒入後その表面が剝離する檫な心配もない。

\section{2. 液體炭滲劑}

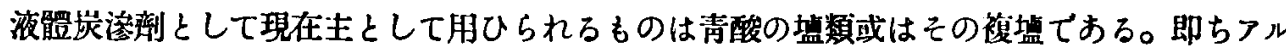

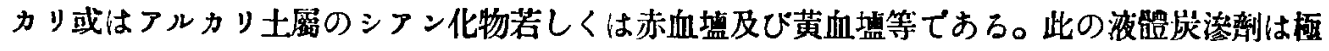

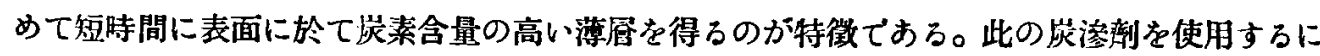
二つの方法がある。

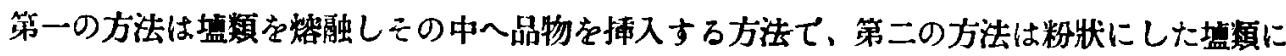

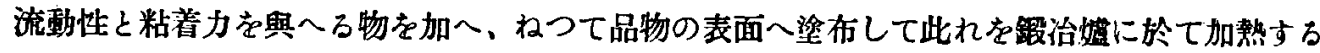
ち法である。

（1）第一の方法は炭港及び燒入に依る形狀のくるいを出來るだけ防止したい鈞合に用ひ ろ。此の方法は前述の如く盐槽中で炭澺するから極めて均一に加熱せられる。故にその形狀の

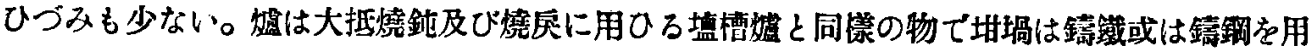
ひる。

此の方法に主として用ひられる盐は KCN で此れを熅融し $850^{\circ}$ 〜 $900^{\circ} \mathrm{C} に$ に保持しその中 に品物を 3〜15 分間挿入する。温度及じ挿入時間等に依り多少異なるが大體 0.03〜0.1 籷の 厚さの均等の炭㳒屡が得られる、時間を長くし温度を上げれば $0.15 〜 0.2$ 粍优の厚さは容易に

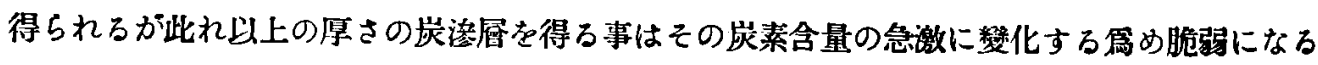
故余り嘿ましくない。

KCN の外に澤山の混合壏が推獎されてるるが何れも賖り好成績でない。そして之等の混合

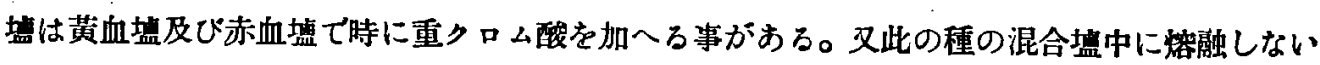
成分がある時があらが此れは種々の形の炭素で例へば石炭及び䯚炭の如きものである。熔融さ れる部分は前述の如く青酸のアルカリ盐類に赤血盐、又は黃血盐、時に炭酸盐（例へば $\mathrm{Na}_{2} \mathrm{CO}_{3}$ ) 等を加へたものである。 
最後に青化加里を用ふる時はシアン瓦斯が出て此れが甚しく有毒であるから此れ存防止する 完全なる設備の必要な事を附け加へて置く。

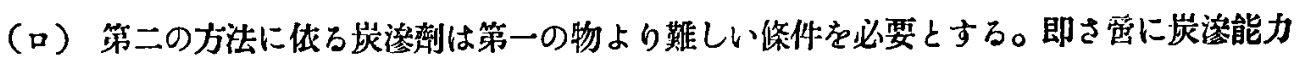

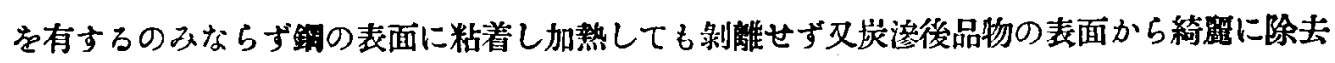
する事の出來るものでなければならない。此の方法に一般に用ひられる最も簢單な炭渗恋は粉

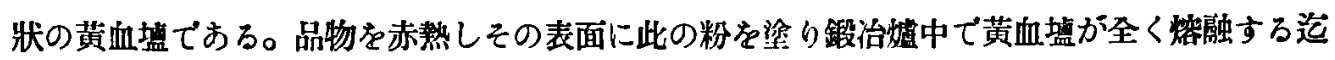
加熱し然万後水中茄入をする。

同じ方法で用ひられるものに（黄血盐＋青化加里）或は（黄血塩十重ク口ム酸加里）等の混 合物がある。

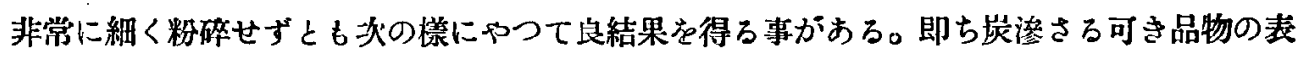

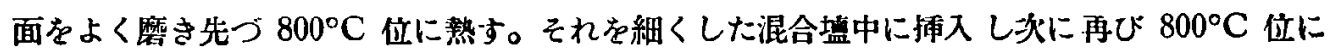
加熱し又混合野中に捅入する。斯くの如くして炭渗劑が固く充分な厚味に付く迄、上上の操作 を繰り返へす。然し大體二回の加熱で充分である。

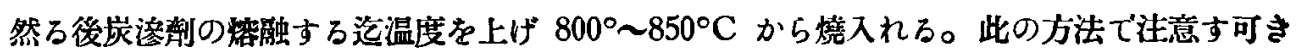
事は鎆の表面に酸化物がある時はこの炭渗を妨げ る故に酸化物はよく除去しなければならな い。及加整は徐々にしなければならない。

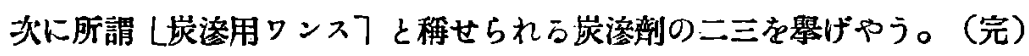

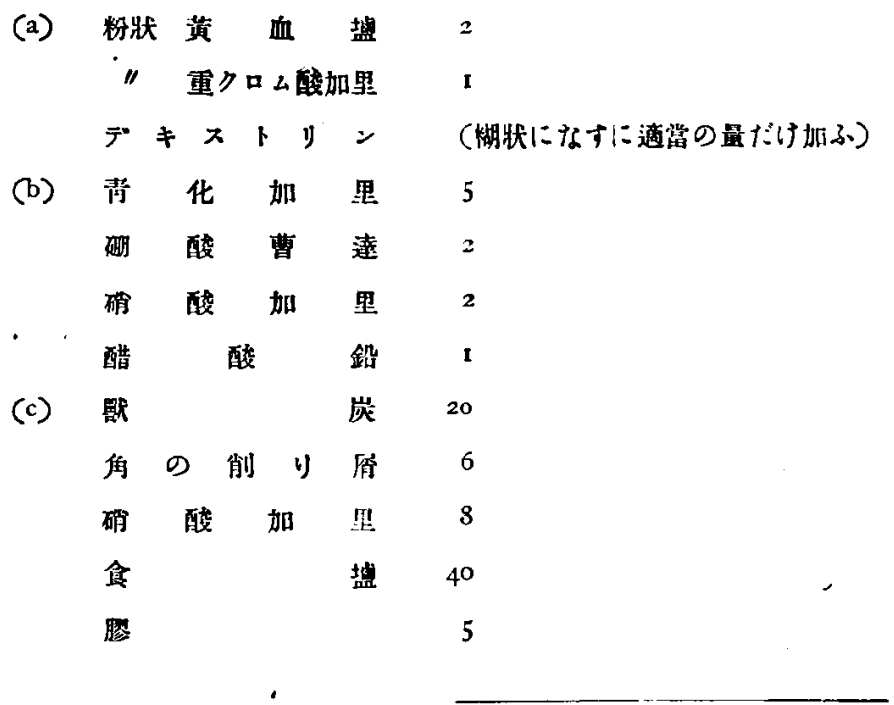

